\title{
需要端予備率に基づく発電・送電系統の信頼度評価
}

\author{
正員 持 舘 靖 典 (東北電力) \\ 正員 斎 藤 浩 海 (東北大) \\ 正員豊田淳一 (東北大)
}

\section{Composite Power Systems Reliability Evaluation based on Demand-Side Reserve}

Yasunori Mottate, Member (Touhoku Electric Power Co., Inc.), Hiroumi Saitoh, Member, Junichi Toyoda, Member (Touhoku University)

This paper proposes new demand-side reliability indices and useful computational techniques for reliability evaluation of composite power systems. These new indices are based on the active power which can reach at each demand spot under generating and transmission network constraints. This conception is defined as "reachable power", and it leads the reserve margin on each demand spot, which is called as "demand-side reserve". If the reachable power is insufficient to satisfy the demand, load curtailment is required. In the proposed approach, the conception of load curtailment area is defined, and the estimate method of load curtailment area is indicated. In case the reachable power exceed the demand, system reliability is evaluated by the demand-side reserve, and the power system is devided into several reliability zones according to the demand-side reserve levels. Small system examples are used to illustrate principles of the proposed approach, and middle system examples show the effectiveness and practicalness.

\section{キーワード：信頼度評価，需要端予備率，供給支障地域，信頼度ゾーン分割，線形計画法}

\section{1. まえがき}

我が国では，需要の増大とともに大都市への需要の 集中傾向が強まり，また電源の遠隔化・偏在化による 送電設㣁の長距離化・大容量化が進んでいる。更に今 後, 広域連系が推進される気運があり, 十分な供給力 の確保と同時に，余裕のある流通設備の確保も不可欠 となると考えられる。一方, 社会生活の高度情報化に より，停笔の与える社会的影響は極めて大きなものと なっおてり, 発電設備と送電設備を含めた供給信頼度 の評価の重要性が，ますます増加している。

本論文では，需要端における評価に焦点を当てた信 頼度指標の提案と，その評価を行う発電・送電系統信 頼度算定の手法について述べたい。評価の基となる指 標として，発電機出力制約および送電ネットワーク制 約の下で各需要端に供給可能な電力(到達可能電力)
と，供給支障が生じるまでの余裕(需要端予備率)とい う新しい概念を導入している。また，需要端予備率の 度合いに応じた信頼度による地域分割の手法を開発し ている。

一般に, 送電系統を含む静的な信頼度評価の有力な 手段の一つとしては, 潮流計算による想定事故解析が 挙げられる。しかし, 通常の潮流計算では発電機出力 を固定的に扱い, 送電線の過負荷情報を得ることがで きるが，最終的にそれが回避可能かどうかを判定する ことはできない。従って, 需要端への電力供給能力を 評価するのには適さず, 需要端側での信頼度評価とい うよりも送電系統の輸送能力の評価法といえる。

我が国では, 長期電力需給計画の策定のための日本 電力調查娄員会による供給予備力の算定法(1) が確立 しているが、需要端信頼度の評洒にまでは至っていな いと考えられる。 
また，確率論的手法に基づく扱う発電・送電系統信 頼度の評価法としては需要端にお打る供給支障量の算 定があり，特に海外において，供給不能電力量期待値 (EENS) 算定する手法が広く用いられている(2) (4)。 しかし，この手法では供給支障が生じない場合には何 の情報も得られず，また供給支障母線は貝荷制限の方 針により変わり, 明確な供給支障地域の概念は存在し ていない。

本提案手法による評価は, まず最初に系統全体の供 給支障の発生の有無を判定し，発生する場合には供給 支障量と供給支障地域, 発生しない場合についても供 給支障が生じるまでの余裕(需要端予備率) とその度合 の地域分布を求めるというものである。すなわち，提 案手法では系統全体の供給信頼度を諩価することのほ かに，個々の需要とネットワークから決まる地域的な 信頼度分布, 地域的信頼度の違いの原因となる送電線 を明らかにすることができる。

本提案手法㳉, 著者らにより, 通常の輸送問題との アナロジーからネットワークモデルを構成した手 法(5) (7) を発展させたものであり, 電力回路の性質(位 相角制約)を組み込むことにより，より現実的な信頼 度評価が可能となった。また，上げ方向予借力，下げ 方向予備力などの概念を導入している。

\section{2. 提案する需要端信頼度評価の指標と概要}

提案する信頼度評価法の基本的な考えは，「需要端 における信頼度を, 電力の輸送システムを経由して電 源から需要端へ到達可能な電力で評価する」というも のである。

この各負荷に到達可能な電力を“到達可能電力”と定 義する。発電機出力制約と送電ネットワーク制約によ り到達可能電力の上下限が定まり，図1に示すように 需要電力がその上限を超えれば供給支障, 下限を下回 れば供給過剩が生じることになる。

本論文では, 到達可能電力の上限と需要電力の差を “上げ方向需要端予借力”，下限と需要電力との差を “下げ方向需要端予備力”と定義している。重潮流によ る送電容量制約が問題となるのは主に上げ方向であ り，本論文では特にことわらない限り，上げ方向の問 題を中心に取り上げている。下げ方向が問題となるの は, 夜間などオフピーク時に原子力発電所など最小出 力の大きな電源が偏在化したり，線路補修などにより 十分な流通経路が確保できなくなったりしたとき, 地 域的な供給過剩を監視する重要な評価因子となる。

提案する需要端信頼度の評価アルゴリズムを図 2 に 示した。まず各需要端に到達可能な電力が, それぞれ

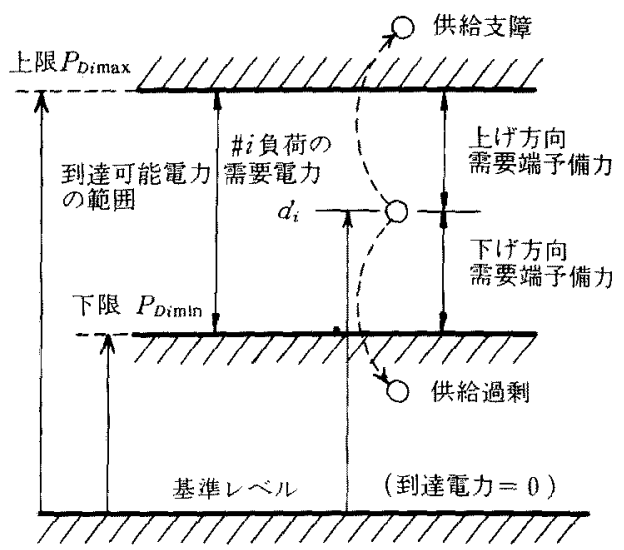

図 1 到達可能電力の概念

Fig. 1. Concept of the reachable power.

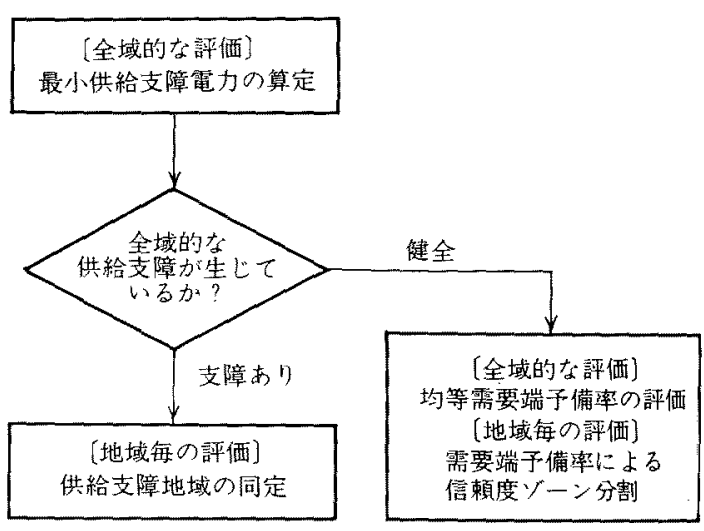

図 2 提案する需要端信頼度の評価 アルゴリズム

Fig. 2. Proposed algorithm for demandside reliability evaluation.

の需要を上回ることができるか検討し，流通経路の十 分性を確認する。これが最小供給支障電力の算定であ り，その結果により系統全体の供給支障の有無を判定 する。供給支障が発生する場合には，供給支障地域上 供給支障の原因となる弱い線路の同定を行う。ここで 供給支障地域とは, 到達可能電力の上限を超えた需要 端である。供給支障の生じない場合には，各需要端へ の到達可能な電力を全系統で均等化するように分配し て, 均等需要端予備率で采統全体の信頼度を評価す る。合わせて到垟可能な電力の余力の大小により系統 を信頼度ゾーンに分割する。

\section{3. 需要端信頼度の評価手法}

〈3・1〉 ネットワークモデル 潮流分布を散密に 扱う場合には非線形問題として記述する必要がある 


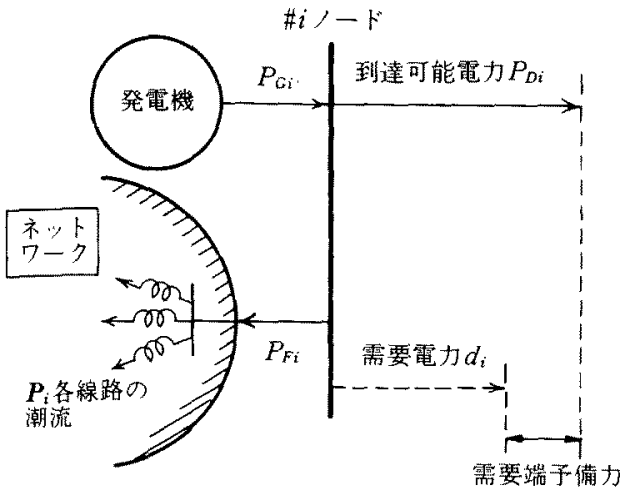

図 3 各ノードに扔ける電力潮流の関係

Fig. 3. Relationship among the power flow on each node.

が，本論文では，有効電力フローの問題，需要端評価 の閣題に焦点をあてるため，潮流分布の決定には直流 法による線形モデルを用いて簡略にしている。

図3に示すように，\# $i$ ノドの発電機出力を $P_{G i}$, ネットワークへの送出電力を $P_{F i}$, \# $i$ 需要端への到達 可能電力を $P_{O i}$ とすれば,

$$
\begin{aligned}
& P_{G i}-P_{D i}=P_{F i} \\
& \left(\begin{array}{c}
P_{F 1} \\
\vdots \\
P_{F n}
\end{array}\right)=\left(\boldsymbol{B}_{\text {node }}\right)\left(\begin{array}{c}
\delta_{1} \\
\vdots \\
\delta_{n}
\end{array}\right)
\end{aligned}
$$

あるいは，

$$
\begin{aligned}
& \boldsymbol{P}_{G}-\boldsymbol{P}_{D}=\boldsymbol{P}_{F} \\
& \boldsymbol{P}_{F}=\boldsymbol{B}_{\text {node }} \cdot \boldsymbol{\delta}
\end{aligned}
$$

が成立する。ここで， $\boldsymbol{B}_{\text {node }}$ は直流法によるネットワ 一クのノードサセプタンス行列， $\delta$ は電圧位相角べク トルである。本論文でとりあげる手法では，各線路の 潮流 $\boldsymbol{P}_{f}$ の上下限制約を判定する必要があり，ネット ワークの接続行列 $C$ を用いると，

$$
\begin{aligned}
& \boldsymbol{P}_{\boldsymbol{F}}=\boldsymbol{C} \cdot \boldsymbol{P}_{f} \cdots \ldots \\
& \boldsymbol{P}_{\boldsymbol{f}}=\boldsymbol{B}_{\text {ine }} \cdot \boldsymbol{C}^{t} \cdot \boldsymbol{\delta}
\end{aligned}
$$

が成立㐫る。ここで， $\boldsymbol{B}_{\text {ine }}$ は各線路のサセプタンス を対角要素とする対角行列である。

\section{〈3・2〉LPによる需要端信頼度指標の算定}

提案手法の基本となる計算は，（i ）供給支障電力の 算定，および(ii)均等需要端予備率の算定の二つであ り，線形計画 $(L P)$ 問題として定式化する。

（1）供給支障電力の算定評価の第一段階で は, 各需要端の需要に等しいだけの発電力を, 流通経 路を経由して分配可能であるかを評価する。(8)式の 制約の下で，（5)式は系統全体の供給支障を最小化す
ることになるので、Zが 0であれば供給支障はないこ とになる。るが 0 以外(必ず正)の数值になれば，それ は最小供給支障量を表し, 同時に供給支障電力を最小 にする発電機出力パターン, 供給支障の生じる需要端 などが決まることになる。

$$
\min z=\sum_{i}\left(d_{i}-P_{D i}\right)
$$

subj. to （1），（2），(4)式の各等式制約

$$
\begin{aligned}
\boldsymbol{P}_{G \min } \leqq \boldsymbol{P}_{G} \leqq \boldsymbol{P}_{G \max } \\
\boldsymbol{P}_{f \min } \leqq \boldsymbol{P}_{f} \leqq \boldsymbol{P}_{f \max } \\
\boldsymbol{P}_{D} \leqq \boldsymbol{d} \cdots \cdots
\end{aligned}
$$

ここで，添字の $\min , \max :$ 下限制約と上限

制約, $\boldsymbol{d}:$ 需要 $d_{i}$ のベクトル

（2）均等需要端予備率の評価供給支障がない 場合，需要端に扔ける到達可能電力の組合せは無限に ある。しかし，電力系統に信頼度に関して地域的公平 性が望まれる場合には，すべての需要端での予備率を 同等に保った状態で系統全体の信頼度を評価するとよ い。この考え方を実現するためには，各需要端での到 達可能電力の需要端予備率を均等化することにあると 考えられるので，次の定式化が可能である。

(1 11 ) 式の左辺は, 各需要端の予備率を表してお り，(9)式と組み合わせて各需要端の予備率を均等化 して吏に最大化を図っている。(10)，(8)式では大小 関倸が逆転していることに注意されたい。

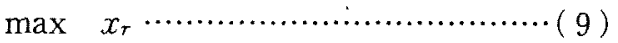

subj. to (1)，(2)，(4)，(6)，(7)の各式

$P_{D} \geqq d$

$\frac{P_{D i}-d_{i}}{d_{i}}=x_{r}$

〈3・3〉信頼度の大小による地域分割 電力系統 の状態は，供給支障が発生する場合と，発生しない場 合の二つに分けられる。供給支障が発生する場合に 沽，供給支障が発生する可能性のある母線の群(供給 支障地域) を求め，発生しない場合には需要端予備率 の度合いに応じた信頼度の地域的分割を行う。

（1）供給支障が起こる場合 系統全体として供 給力が十分であってもネットワーク制約により供給支 障が発生する場合には，その原因となる線路(群)が存 在し，系統性その線路(群)を境として，図4のように 需要を上回る電力を供給できる地域と，そうでない地 域(供給支障地域)に2 分されることになる。逆の立場 でいうと，供給支障地域内で需要を減少させれば線路 の過負荷を回避できることを意味している。

いま，図4の\#3の線路の潮流が送電容量制約に上 り制限されると，これと回路的に並列している甘１， 
\#20線路の潮流もそれ自身の送電容量以下ではある が，潮流制約を受汀ることになる。現実のネットワー クでは送電容量により制限された線路と並列する線路 の組合せは複数あるので，図 4 の上うに健全地域と供 給支障地域省分離する線路の組合せの選定法が必要と なる。

供給支障電力の算定法を利用した供給支障地域判定 のアルゴリズムは次のようになる。

（i）供給支障電力が最小になる各需要端への到達 可能電力の分布を決定する。

（ii）供給支障と判定された需要端への到達可能電 力を, その母線の需要と等しく固定して, 再び供給支 障電力最小の問題を解き, 各需要端への到達可能電力 を求める。

(iii）（ii）の操作を反復する。ここで,LPの実行 可能解が存在しないとき,すなわち各需要端への到達 可能電力が求まらないとき, 供給支障地域の判定は終 了となり, 供給支障地域は, それまでに供給支障が生 じると判定された需要地点すべてとなる。言い換えれ ば，本論文でいう供給支障地域とは，その地域内のす べての需要に対して負荷制限をしなければ，LPの実 行可能解が求まらないという地域を意味している。

（2）供給支障が起こらない場合需要端予備率 の度合いによる地域的分割(信頼度ゾーン分割) 注, 次 のように均等需要端予備率の評価法を利用して行う。

(i ) 均等需要端予備率の算定を行引。

(ii) 系統を均等需要端予備率以上の需要端予備率 をとれる余裕のある地域と，ぎりぎりの余裕のない地 域で 2 分割する。具体的には，均等需要端予備率のと きの到達可能電力分布を微小增加させた需要を想定 し，供給支障地域を求めるアルゴリズムを利用して， ぎりきりの余裕のない地域を決める。

（iii）均等需要端予備率までしか需要端予備率をと

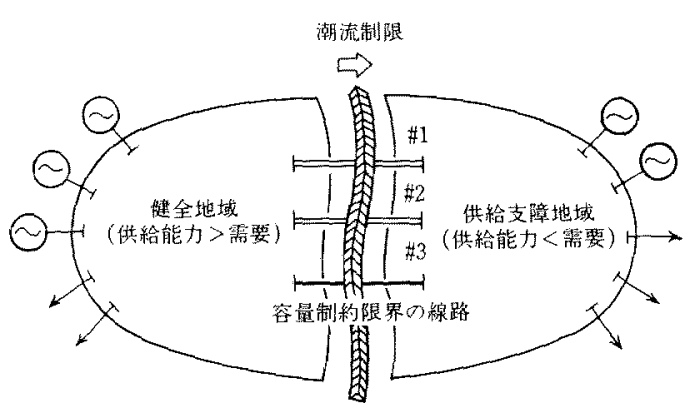

図 4 供給支障地域の概念

Fig. 4. Concept of the load curtailment area.
れない地域はそのときの到達可能電力分布で固定し て, 更に余裕のある地域について, 信頼度ゾーン分割 を考党る。

（iv）以上の（i ），（ii），(iii）の操作を反復する。 (i)の結果, 到達可能電力の総和が総発電能力に等し くな机、信頼度ゾーン分割は終了となる。

\section{4. モデル系統における検討例}

\section{$\langle 4 \cdot 1\rangle$ 小規模系統の場合}

（1）供給支障が発生する場合 図 5 に示す3機 4 母線, 負荷需要数 4 , 線路数 4 の小規模系統に提案 手法を適用した結果について説明する。この系統では 供給支障が発生し, 需要\# 3,4 が供給支障地域と判定 される。供給支障の原因となる線路は, 潮流が送電容 量で制限される線路(\#1-\#4)と，それとループを組む 線路(\#2-\#3)である。この判定の流れを以下に示す。

（i）供給支障電力最小の問題を解いた結果，線路 （\#1-\#4)の潮流が送電容量により制限されるため, 需 要井 4 に $12.5 \mathrm{MW}$ の供給支障が発生する。

（ii）次に，需要夰 4 で負荷制限しないケースにつ いて再び供給支障電力の算定を行うと，需要井 3 で供 給支障が発生する。ただし，その場合の供給支障量は $16.7 \mathrm{MW}$ となり, 需要井 4 で負荷制限する場合より も供給支障量が増大する結果となる。

（iii）次に，需要\# 3 と\# 4 で負荷制限を行わない場 合について再び供給支障電力の算定を行うと, LPの 奏行可能解が存在しない。これは，負荷需要\# 3 と\#4

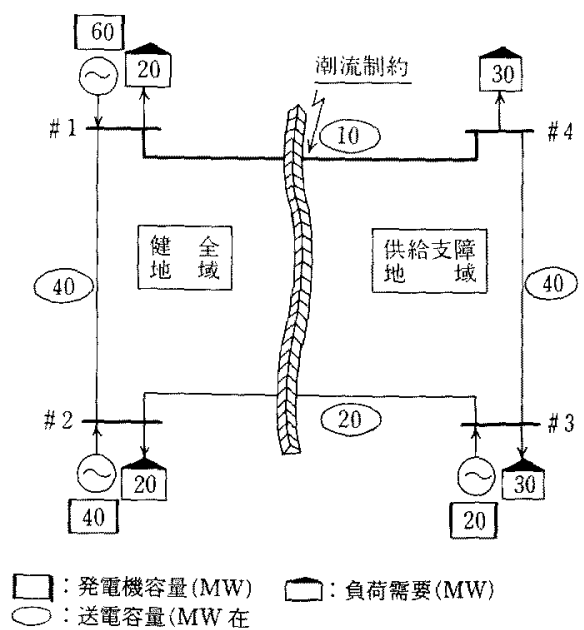

各線路のリアクタンス $(\mathrm{pu \Omega}): x_{12}=0.1, x_{14}=0.4, x_{23}=$ $0.2, x_{34}=0.1$, 各ノードの電圧は 1 puに設定

図 5 小規模系統例とその供給支障地域 Fig. 5. A small system example and the load curtailment area. 


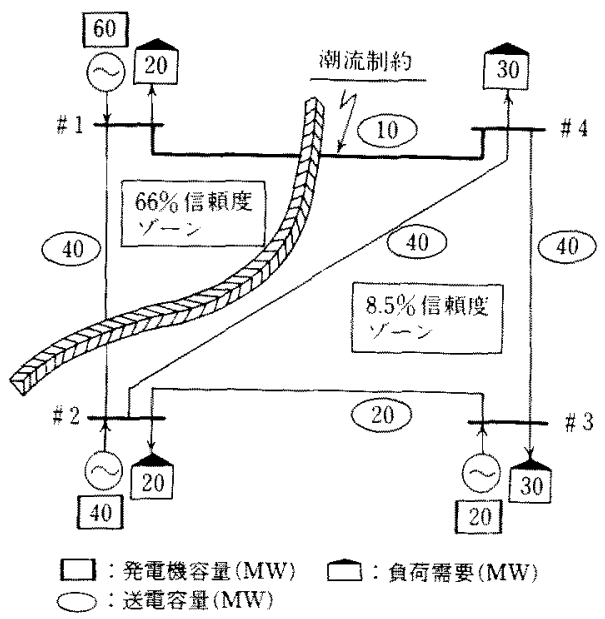

$x_{24}=0.1$ pu $\Omega$, 他住图 5 占同じ

図 6 小規模系統例とその信頼度ゾーン分割 Fig. 6. A small system example and the reliability zones.
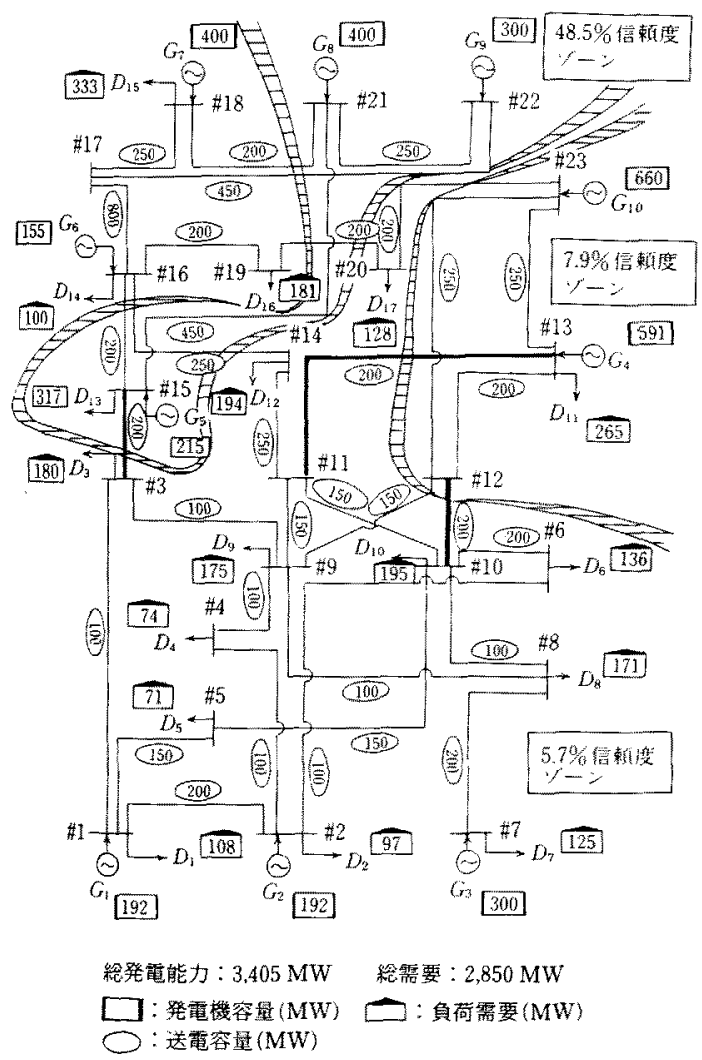

图 7 中規模系統例とその信頼度ゾーン分割

Fig. 7. A middle system example and the reliability zones.
に同時に需要電力が到達することは，ネットワーク制 約上ありえないことを表している。従って，供給支障 地域は需要井 3 と\# 4 D2つの时線となる。

（2）供給支障が起こらない場合 図 5 の系統の 母線进 2，4間に線路を加えた場合である図60系統に 提案手法を適用すると，この系統では供給支障が解消 されることがかかる。またこの系統のネットワーク を無視した系統予備率は $20 \%$ であるが，均等需要端 予備率の算定を行った結果は線路(\#1-\#4)の潮流が送 電容量により制限されるため, 均等需要端予備率は $8.5 \%$ となる。次に，需要端予備率による系統の分割 を行うと，均等需要端予備率の $8.5 \%$ 以上の需要端予 備率をとれる地域は需要井10みとなり, 系統流信頼 度の違いにより 2 分されることになる。

ここで，穤要\#１の需要端予備率はネットワークを 無視した系統予備率より大きなっている。これは,

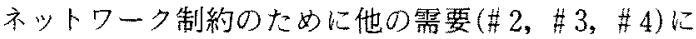
供給できなくなった発電機\#10出力を，すべて需要

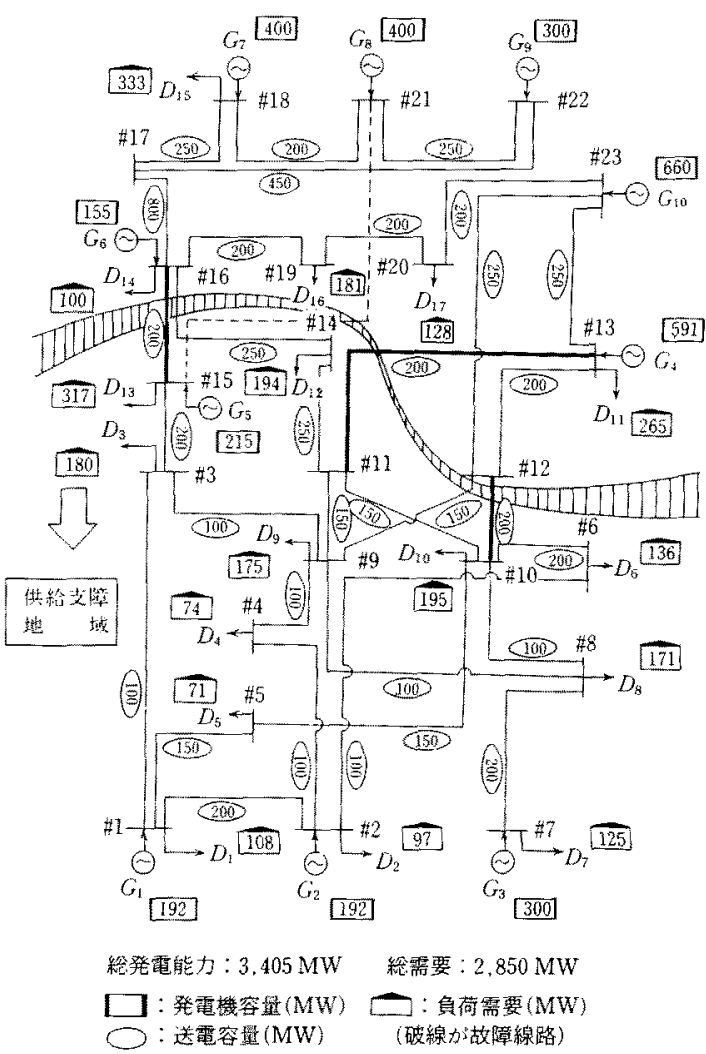

図 8 中規模系統例々その供給支障地域

Fig. 8. A middle system example and the load curtailment area. 
\#1に割り振ったために見掛け上生じるものである。 需要端予備率が系統予備率より大きくなる地域は, 六 ットワーク制約が問題とならない地域であり，その需 要端予備率の差は信頼度のかたよりを表している。

〈4・2〉 中規模系統の場合 図 7 に示す 10 機 23 母線の中規模系統に提案手法を適用した結果について 説明する。この系統では供給支障は発生せず, 均等需 要端予備率は $5.7 \%$ と算定される。この値はネットワ ークを無視した系統予備率の $19.5 \%$ に対し，かなり 低い值となっており，本論文のアルゴリズムによれ ば, その原因となる線路は図中の太線の線路と判定さ れる。また, 需要端予備率の度合による信頼度の地域 的分割を行うと, 系統は需要端予備率 5.7, 7.9, $48.5 \%$ のつの信頼度ゾーンに分割され, 系統の大 部分が $5.7 \%$ と低い需要端予備率になることがわか る。

図 7 の線路(\#15-\#21)にルート事故が生じた場合を 想定した図 8 の系統では, 供給支障が起こると判定さ れ, 最小供給支障電力は母線\# 15 の需要端で 14.9 MW が供給不能となることがわかる。また, 供給支 障地域の判定を行うと, 図のように系統の大部分で供 給支障が生じることがわかり, 全域的な評価ではわか らなかった事故の影響の重大さを認識できる。

\section{5. むす び}

提案手法の特徵は以下のと抢りである。

（1）線形近似の式を用いて扔り収束性の問題がな く，LPによる高速性が期待できる。逆にいえば，本 手法の限界は非線形問題を線形化した点にある。

（2）送電ネットワーク制約による供給支障の有無 と需要端への電力供給能力に関する情報が得られる。

（3）信頼度指標として到達可能電力と需要端予備 率という単純な概念を用いるため, 算定された結果が 直観的に理解しやすいものとなる。

（4）供給支障地域と需要端予備率の度合による信 頼度ゾーン分割の概念を導入し, 系統内の信頼度分布 を表現することを可能としている。

提案手法は比較的単純で, 次のような系統運用・計 画の支眆ツールとして広い応用が考えられる。

（i）通常の潮流計算と組み合わせた想定事故評価 の支援

（ii）線路補修計画策定の支援

（iii）電源起動停止など需給運用計画支援

(iv) 電源設備・送電設備の計画策定支援

な抢, 本研究の遂行にあたっては, 東北電力(株)技 術部の関係者, 皆川部長をはじめ多くの方々の御意見
御討議をいただいている。深甚の謝意表する。 (平成 4 年 11 月 26 日受付, 同 5 年 5 月 26 日再受付)

\section{文献}

（1）日本電力調查委員会：日本電力調查報告書における電力需要 想定招よび電力供給計画算定方式の解説（平 4)

(2) CIGRE WG 03 of SC 38 : Power System Reliability Analysis. Application Guide (Lesley Kelley-Regnier. Ed) (1987)

(3) CIGRE TASK FORCE 38-03-10: "Composite Power System Reliability Analysis Application to The New Brunswick Power Corporation System", CIGRE Reliability Symposium (1991)

(4) R. Billinton \& R. N. Allan: Reliability Assesment of Large Electric Power Systems (1988) Kluwer Academic Publishers

（5）諏訪・陳・豊田：「ネットワーク制約を考虐した 2 STEPLP 法 による信頼性の評価」, 電気学会電力技術研資, PE-90-128 (平2)

(6) L. N. Chen, H. Suwa, J. Toyoda: "Power Arrival Evaluation of Bulk System Including Network Constraints Based on Linear Programming Approach", IEEE Trans. Power System * 6, 37 (1991)

(7) J. Toyoda, L. N. Chen, T. Minakawa \& T. Yamada "New Indices and Computational Techniques for Compos. ite Systems Reliability Evaluation", The paper of CIGRE Reliability Symposium, 1 A-01, p. 1 (1991)

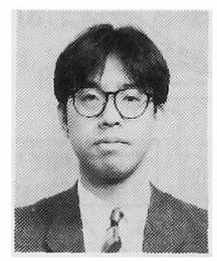

\section{持 舘 靖 典 (正員)}

昭和 42 年 8 月 11 日生。平成 3 年 3 月 東北大学工学部電気工学科卒業。同 5 年 3 月同大学大学院博士前期課程修了。現 在, 東北電力 (株) 勤務。

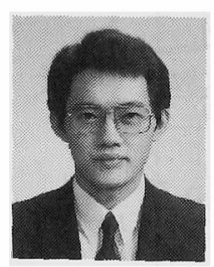

\section{斎 藤 浩 海 (正員)}

昭和 35 年 7 月 19 日生。平成元年 3 月 東北大学大学院博士課程修了。同年 4 月 同大学工学部助手, 4 年 4 月同電気工学 科助教授, 現在に至る。工学博士。

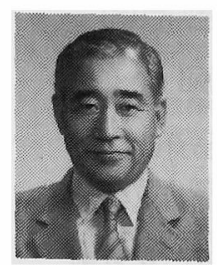

\section{豊 由淳一(正員)}

昭和 9 年 7 月 9 日生。 38 年 3 月東京 大学大学院博士課程修了。同年 4 月成蹊 大学工学部電気工学科助教授, 47 年 4 月同教授。58 年 4 月東北大学工学部電 気工学科教授, 現在に至る。工学博士。IEEE, CIGRE会 員。 